\title{
Afro-American Literature: The Analysis of Gorilla, My Love by Toni Cade Bambara
}

\section{Kustinah $^{1}$}

English Education Study Program

Universitas Widya Dharma Klaten

Indonesia

\section{Sri Haryanti ${ }^{2}$}

English Education Study Program

Universitas Widya Dharma Klaten

Indonesia

haryanti.sirod@gmail.com
Suhud Eko Yuwono ${ }^{3}$

English Education Study Program

Universitas Widya Dharma Klaten

Indonesia

Umi Sholihah $^{4}$

English Education Study Program

Universitas Widya Dharma Klaten

Indonesia

Citation: Kustinah, Haryanti, S., Yuwono, S. E., \& Sholihah, U. (2021). Afro-American literature: The analysis of gorilla, my love by Toni Cade Bambara. Notion: Journal of Linguistics, Literature, and Culture, Vol 3(1), p. 18-29. http://doi.org/notion.v3i1.3547

\section{Article Info}

Article History

- Article Received

$24^{\text {th }}$ January 2021

- Article Accepted $19^{\text {th }}$ April 2021

\section{Keywords}

Afro-American

Literature

Short story

Sociology of Literature

Psychology of

Literature
It is said that Afro-American literature is the body of literature produced in the United states by writers of African descent. Today, Afro-American literature has become accepted as an integral part of American literature. In broad terms, AfroAmerican literature can be defined as writings by people of African descent living in the United States. This qualitative study analyzes a short story entitled Gorilla, My Love written by a female Afro-American writer, Toni Cade Bambara. The analysis of the study aims at answering the three problem formulation: (1) states the literariness of the text (2) explains how the literariness of the text play as a means to symbolize a "broader" text (the universe) and (3) writes the proof of mental evidences taken from the text. In analyzing the short story, this study uses Sociology of Literature and Psychology of Literature. The two theories help readers understanding the theme of the short story by reading the explanation about how the narrator of the story set the plot. This study uses narrative as its approach since this is a literary study where a short story is analyzed through its narrative structure. The conclusion of the study provides the proof of its research benefits: giving information to readers about the following: (1) all about Afro-American literature plus its life-experience, family-values, etc. (2) how a literary work can connect its readers to their life and (3) an understanding that a reading-act strengthens the definition that a literary work is as a portrait of human experience. 


\section{Kustinah, Haryanti, Sri, Yuwono, Suhud Eko, \& Sholihah, Umi Afro-American Literature: The Analysis of Gorilla, My Love by Toni Cade Bambara}

\section{INTRODUCTION}

The so-called term of Minor to manor becomes the background of this study. Minor here refers to a small thing while manor means something bigger. As stated by $\mathrm{He}[1]$ that in minor literature everything takes on a collective value. Whereas, large nations' literature" implies issues that cannot be limited to 'minor literature'. In American Studies, a literary work can tell about the universe. From a little thing, in this case a short story, readers can analyze the value of life, of the universe. In University Writing Center, it is said that literary analysis looks critically at a work of fiction in order to understand how the parts contribute to the whole[2]. That's why a theory of minor to manor exists.

This research uses a short story entitled Gorilla, My Love written by Toni Cade Bambara. She is a female Afro-American writer. Published first in 1972, Toni Cade Bambara's Gorilla, My Love has been celebrated for its realistic depiction of the African American community, for its almost musical rendering of Black English, and for the resilience and energy of its first-person narrators[3]. Her writings were praised for capturing the essence of real events and real people. In a review of Gorilla, My Love, a writer remarks that the stories "are among the best portraits of black life to have appeared in some time. Written in a breezy, engaging style that owes a good deal to street dialect". A New York Times reviewer praises the stories in the debut collection as "tough, violent, funny, and frantically relevant." Many of the narratives in Gorilla, My Love are told from the viewpoint of young women who navigate the challenges of identity and agency in their adolescence[4].

Some researches on short stories analyzed from social and psychological aspects had been done. They are, first "A Sociological Approach of Literature in Short Story Senyum yang Kekal by Korrie Layun Rampan" written by Mursalim[5] with the reason that the sociology of literature is applied in the research because it increases the understanding of literature in relation to society, explains that imagery is not contrary to reality although literary works are imaginatively consumed, but the imaginative framework cannot be understood outside the empirical framework and literary work is not merely an individual symptom but a social phenomenon. Second, "Personality and Individual Differences: Literature in Psychology- Psychology in Literature" written by Aras[6] with the statement that there is a very strong correlation between literature and psychology since both of them deal with human beings and their reactions, miseries, desires, and their individual and social concerns by means of different concepts, methods, and approaches. Third, "Kajian Psikologi Sastra dalam Cerpen Perempuan Balian' Karya Sandi Firly" written by Setiaji[7] who used sentences containing structure and psychology as the research data. Forth, "Aspek Kepribadian Tokoh Utama dalam Cerpen Cerita Pendek yang Panjang Karya Hasta Indriana, Kajian Psikologi Sastra, dan Implementasinya sebagai Bahan Ajar sastra di SMA" written by Rahayu[8] with the result that personality aspect in the story includes personality types of a person who has empathy and life motivation.

The analysis of this research tries to find the literariness of the text and at the same time proves the value inserted in. The literariness here refers to the power of words (i.e. certain dictions with symbolic meaning), figurative language, unusual grammar and other things which differentiate it from an ordinary text (non-literary text). As stated by Ahmadi[9] that to understand the psychological elements in literature is not easy because the researcher must be able to interpret the symbols contained in literary works. The literariness of the text is used as data to confirm a definition of literature: Literature is as a portrait of human experience. Literature also deals with human beings in society with regard to their undertaking to adapt to and change society[14]. Toni Cade Bambara uses Gorilla, My Love as a mirror of Afro-American people with their life-values. She aims at provoking the readers' mind to grab the message of the text.

This study sets three problem formulation (1) what is the literariness of the text? (2) in what way does that literariness picture the real life (universe)? (3) how do we find the mental evidences from the text? The followings are the research objectives or the answers of the previous problems: (1) states the literariness of the text (2) explains how the literariness of the text plays as a means to symbolize a broader 


\section{nOTI \\ Journal of Linguistics, Literature, and Culture}

text or the universe (3) writes the proof of mental evidences taken from the text.

Seeing the research objectives above, the followings are the benefits that a reader can get: (1) somebody can add his/her knowledge about AfroAmerican literature plus its life-experience, familyvalues, etc. (2) somebody will learn how a literary work can connect its readers to their real life (3) somebody will get an understanding how a readingact strengthens the definition that a literary work is as a portrait of human experience.

\section{METHODOLOGY}

This study applies qualitative Method. Based on Creswell[15], there are 5 approaches in a qualitative research: narrative, phenomenology, grounded theory, ethnography and case-study. This study uses narrative as its approach since this is a literary study where a short story is analyzed through its narrative structure. Narrative study focuses on narration, story or description about series of events related to human's experience. Narrative is a word that is used across a broad range of contexts, and its meaning varies accordingly[10]. This study examines the experiences of the narrator in the short story entitled Gorilla, My Love as the source of data[16].

There are 2 literary studies used to analyze the short story: sociology and psychology of literature. Social psychology is focused on helping us understand and explain social behavior. Social theories are generally centered on specific social phenomena[11]. The first reason is because the writer of the short story uses Afro-American people as the main background of the story. The second reason is psychology of literature is used to help readers understand the circumstances faced by the narrator of the short story. Literary psychology is the study of literature that views works as psychological activities. The author will use creativity, taste, and initiative in working. Readers in response to the work do not apart from each other's psyche[7]. Both literature and psychology are preoccupied with similar issues and both may barrow from each other to offer multiple interpretations and perspectives[6]. Some quotations from Endraswara[17] are used as the basis of those literary studies. The first is "a literary work will always perform the phenomena in a society." The sociology of literature studies the relation between literature and society. A social life will trigger an appearance of a literary work. Literature is the expression of human life which is connected to societal roots. The important thing in sociology of literature is the concept of mirror. In this relation, literature is assumed as a mimetic society.

The second quotation is "literature is not only the effect of social causes but also the cause of social effect." Sociology of literature focuses on human's problem. Literature performs human's struggle in deciding their future, based on imagination, feeling (emotion), and intuition. Human's struggle will always give a color to a literary text. There are 3 perspectives relating to sociology of literature: (1) a study which sees a literary work as a social document. It reflects the situation of the time when a literary work is produced (2) a study which proves that a literary work is a mirror of situation of its writer (3) a study which catches a literary work as a manifestation of historical events and socio-cultural situation.

In relation to psychology of literature, Endraswara[17] states that there is an assumption that a literary work is a product of psychological aspect and the thought of its writer in subconscious situation. Then, when everything is clear, it is written in a conscious form. The space between conscious and subconscious always gives a color to the process of a writer's imagination. Basically speaking, psychology of literature will be supported by 3 approaches at a same time: textual approach, receptive-pragmatic approach, and expressive approach.

\section{RESULT AND DISCUSSION}

The opening sentence of the short story reveals an importance of certain time when the narrator introduces one member of her family, Hunca Bubba. This study believes that the narrator speaks someone's identity in a large context; she not only talks about the name, both surname and complete name but also inserts something more, the thing that can be found in the whole plot. This study finds a diction which is very interesting to analyze. See the quoted sentences below:

"That was the year Hunca Bubba changed his name. Not a change up, but a change back, since Jefferson 


\section{Kustinah, Haryanti, Sri, Yuwono, Suhud Eko, \& Sholihah, Umi Afro-American Literature: The Analysis of Gorilla, My Love by Toni Cade Bambara}

Winston Vale was the name in the first place. Which was news to me cause he'd been my Hunca Bubba my whole lifetime, since I couldn't manage Uncle to save my life." (first paragraph, line 1-4)

This study italicizes the word Uncle because it leads to certain interpretations. First, a question appears on our mind, why Uncle here is written with the capital letter of $\mathrm{U}$. This study believes that the narrator sends a message to its readers that the figure of Uncle here is important in narrator's life. Another interpretation is, Uncle here can mean Uncle Sam, a symbol of United States of America. As we have known earlier that Bambara has a role in struggling to make Afro-American literature as a part of American literature in a white-dominated society. In the above quotation, the narrator sends a kind of messages that a pride of self-identity informs the readers about the situation faced by the narrator. Identity which Wallerstein and Blakeslee mention is an acute version of a process of 'finding oneself which the social conditions of modernity enforce on all of us. This process is one of active intervention and transformation. The psychology of self and identity is as one theme[18] has often been accused of unduly neglecting. Since a literary work performs a community-life, we can interpret here that the narrator experienced a hard life since she couldn't manage her Uncle to save her life. The first term of Uncle here represents the real Uncle with the name of Jefferson Winston Vale; the second term of Uncle here may represent Uncle Sam, a nation, a country where the narrator lives. There is also a sense of disappointment form the quoted sentence. This study uses a quotation from the Free Library of African American Review (2002) to strengthen the above interpretation:

"Gorilla, My Love is framed by the consciousness of a child or adolescent protagonist; voiced in the first person - with the singular "I" drawing its energy and power from an implied "we" of community."

Seeing the three lines above, we can see here that "I" as the narrator of the short story implies "we", her community, the Afro-American people. Besides, Uncle Hunca Bubba represents Uncle Sam. The keyword for this interpretation is the word of community. The short story is opened by introducing the Uncle that symbolizes "another Uncle". The theory of minor to manor is approved here. One character of the short story, Uncle Hunca Bubba symbolizes Uncle Sam with its wider interpretation. In another context, the quoted sentence inserts information that Uncle Sam couldn't manage the life of Afro-Americans. The explanation is clear since this study applies sociology of literature to analyze the short story. We see here that Bambara creates a narrator who speaks about her people, the AfroAmerican society who live in America or commonly termed as Uncle Sam.

The following lines of the first paragraph discuss the idea of self-identity. A sense of identity beyond gender roles can be seen in the quoted sentences as follow:

“. . . . . So far as I was concerned it was a change completely to somethin soundin very geographical weatherlike to me, like somethin you'd find in a almanac. Or somethin you'd run across when you sittin in the navigator seat with a wet thumb on the map crinkly in your lap, watchin the roads and signs so when Granddaddy Vale say "Which way, Scout," you got sense enough to say take the next exit or take a left or whatever it is. Not that Scout's my name. Just the name Granddaddy call whoever sittin in the navigator seat. Which is usually me cause I don't feature sittin in the back with the pecans."

The interpretation of the above quotation is this study analyzes the word Grand before the word of daddy as certain or special tendency. This study believes that Bambara underlines the significance of family's role for the narrator. Grand literally means something very big; in this context, big could refer to a big role of a daddy in narrator's life. In general, we can also assume that this is a statement telling that in an Afro-American family, Granddaddy is an important figure, it inserts familial values. Let's now relate that sense of identity beyond gender roles. See the diction of navigator seat. Generally speaking, it can be understood that a navigator seat is usually a male position while the narrator of the short story is a young female character. We imagine here that the seat here is in a car as a symbolic interpretation because a navigator seat could also be found in an aero plane, for instance. Bambara exposes her ideals about gender roles as she pit the female narrator in a male position. Bambara creates the narrator as a voice who speaks an equality for women in a male- 
dominated society. The way Granddaddy uses Scout to call whoever takes the navigator seat strengthens an opinion that in Afro-American society, women's role is very important. The explanation is clear: we read from the lines that the one in navigator seat decides, chooses and directs the way the vehicle drives to. The contextual meaning of Scout here is that the female narrator is having an important position in that car. Car may symbolize a vehicle or a way of life. The narrator of the short story is given a crucial role in shaping her life because she may decide where to go, she may choose the turn to take and set the direction of life-journey. The atmosphere-setting when the narrator is described as having a car-drive with Granddaddy may symbolize a life-journey. As the narrator is still very young, Granddaddy drives the car but she learns that the family let her to lead the way. The dictions used in the above quotations as roads, turn (take a left), signs; give a wider interpretation for this study believes that those choices of words symbolize a community's way of life. It symbolically explains how the Afro-Americans set their principles of life and apply them in daily life. A car takes a turn and goes to a certain road, it may be close to life-goals. Road and turns are the shaping of their journey in achieving the life-goals, life-ideals. The car symbolizes the shaping of family-values.

Another interpretation of the word Scout in the above quotation is Scout refers to a young age around 9 until 12 years old as secondary school students wearing the scout uniform. It inserts a message that in an early period of life, an AfroAmerican young girl has been taught about familyvalues, an opportunity to shape her ideals in experiencing life. As stated by Halliday[12] as girls who are assertive, willing to fight, and outspoken, Scout and Squeaky illustrate how communities and families infuse their girls with strategies to resist. Bambara emphasizes this point in the last sentence of the above quotation: "Which is usually me cause I don't feature sittin in the back with the pecans." This study believes that the back seat symbolizes an unimportant position on that vehicle. In this context, the narrator of the story has been set or in a narrative way, chooses an important position, not in the back because it is an unimportant position. Logically speaking, the back seat is usually used for the ordinary passengers, they just sit and follow the car to where the navigator leads the driver to move the car.

The second paragraph of the short story reveals a preliminary information about selfdetermination. The narrator writes that her uncle is being in love. The sentences inform the readers that the narrator doesn't like the "psychological condition" of the uncle. Bambara "hides" the explanation why her narration doesn't like the uncle's story about the woman to whom he is in love with. The idea of self-determination is told to readers by the last sentence of the second paragraph "Cause I am a movie freak from way back, even though it do get me in trouble sometime." According to Cherry[11] self-determination can play an important role in how people function in many different areas of their lives. Feeling in control and intrinsically motivated can help people feel more committed, passionate, interested, and satisfied with the things that they do.

It gives a clue to readers that the narrator ignores the attention paid by her baby Jason to their uncle's love-story and moves to the idea of claiming herself as a movie freak. An interesting interpretation appears from the last sentence: why it is said that the narrator puts herself in trouble anytime she watches a movie? A question is set in our mind. This study finds the answer of that question in the third paragraph. Bambara sets the character of her created-narrator through the above sentences. It is seen that the narrator is described as a brave and strong and creative young girl who dares to fight with boys who disturb her and her Baby Jason. The word baby here may refer to a younger brother. Bambara uses the setting inside and outside a movie-theatre to describe the bravery, the strength and the creativity of her narrator. She set her short story in twelve long paragraphs (only two of them are rather short) and this study analyzes each paragraph to find the frame of the story. This study believes that Bambara uses long paragraph in purpose: she insists on giving a complete detail about the narrator's character. All about narrator's response to certain unpleasant situation is written in full description. The unique language of the Black dialect colors the short story in whole, from opening till the closing sentence. 
The fourth paragraph gives a clear explanation about narrator's character. The sentences describe one unexpected situation experienced by the narrator and the writer illustrates how the narrator responds. The choice of using long paragraph shows a detailed explanation about the narrator. This study sees that Bambara uses the first five sentences to show readers that the narrator of the short story feels disappointed about the unexpected film. She and her little brother hope to see a film about Gorilla, but the fact they "are given" a film about Jesus (King of Kings). She illustrates the anger of the narrator by choosing the dictions: "And I am ready to kill, ..." This study analyzes that the dictions must have a relation with the following sentences, as a kind of explanation. As we have known that the narrator of the short story is a young girl; logically speaking, we will have a question in our mind: how can a young girl kill somebody? This study believes that in this case, the writer wants to underline the character of the narrator; she tries to illustrate the disappointment. An interesting explanation is found from the following quotation: "Grownups figure they can treat you just anyhow." This study believes that this is an expression of how a young girl assumes that adult people may act / tell / do a lie to a younger person or children. The quotation inserts an idea of unfair attitude felt by the narrator of the short story. To strengthen this analysis, this study uses the previous sentence of the quotation to show the narrator's boredom as her reason to be mad: "Besides, we see this raggedy old brown film King of kings every year and enough's enough." Pay attention to the repeated words of enough. This is the emphasis. Bambara strongly underlines a unique character that such a young girl can get mad only because of a repeated film on Jesus who is actually a respectful figure in narrator's life. The following lines show that the narrator and her younger brother make noises inside the theatre by yelling, screaming, etc. Then, this study finds an interesting point from the last six sentences of the paragraph: "Then here come the big and bad matron, the one they let out in case of emergency. As she totin that flashlight like she gonna use it on somebody. This here the colored matron Brandy and her friends call Thunder burns. She does not play. She does not smile. So we shut up and watch the simple ass picture." This study underlines the word of "colored". It refers to racial pride because colored means black people or Afro-Americans. In the short story, the matron is the person who is in charge to keep the safe situation when a film is played. Since the narrator and her younger brother make a disturbance, she comes close. We see here that because the matron is a female, big, and colored matron, the narrator and her younger brother obey her. This study believes that the word of colored is very important here. The narrator of the short story respects the matron because they both are colored people. It gives a sense of racial pride. This study also believes that this is also an important theme of Bambara's themes. This study has inserted an idea of self-identity. The narrator of her short story is described clearly when the reaction upon unexpected film and the appearance of colored matron appear, the narrator's self-identity is beautifully written. The message is that there is a strong bond among colored people. The proof is the narrator is trying to do her best to control her anger, her disappointment because the one she faces with is a colored person like she herself. According to Puglisi[13], disappointment is one of the most powerful emotions in fiction, and something all characters must feel at some point in their journey. There are different levels of disappointment, and many causes for it.

The fifth long paragraph of the short story teaches the readers about family values of AfroAmericans. Bambara gives a portrait of it through the voices spoken by the narrator. This study finds an interesting diction in the second sentence: "Cause I realize that just about anybody in my family is better than this god they always talkin about." Pay attention to the word god. It is written in the small letter of $\mathrm{g}$. Literally speaking, god means The Almighty. But this study believes that this diction refers to the previous paragraph where the narrator is said to be disappointed of the repeated film on Jesus. This study assumes that through her narrator, Bambara wants to give information that Jesus is like god for American people, but to underline the family values, Bambara says that every member of her narrator's family is better than Jesus. This study analyzes that the quoted sentence has a hyperbole style to state the importance of family role for an Afro-American young girl. This 
study finds a proof about this idea from the following line: "My mama especially." Seeing this sentence, it is clear that a role of a mother in an Afro-American family is very special or we may say she has an important role or gives a significant influence for the whole family. See the other line: "And my Mama say Get on down from there you big fool, watcha think this is, playtime?" Bambara uses the capital letter of $\mathrm{M}$ for Mama, it means something. From the previous quotation, mama is written in small letter of $\mathrm{m}$. This study assumes that the first mama is an introductory information and the second Mama is the clue or the explanation. When we are talking about family, we surely mention important figures in it, besides a mother; for instance, Granddaddy. See another quoted line: "And my Daddy yellin to Granddaddy to get him a ladder cause Big Brood actin the fool, his mother side of the family showin up." This study believes that Big Brood means big Brother (so we can say that Hazel, the narrator of the short story has an older brother and a younger brother that is Baby Jason). Baby Jason is introduced in the first paragraph of the short story until the fifth paragraph which are being analyzed right now, we can count the number of the family who is involved in the story: Hunca Bubba (Jefferson Winston Vale, the Uncle), Granddaddy Vale, Baby Jason, Big Brood, daddy, mama, Aunt Daisy, Uncle Clayton.

Bambara creates 9 characters for writing Gorilla, My Love. She gives detailed information for each of her created character. This study sees that the given information draws a line on the theme inserted in the plot. The theme is about how the adult treat the younger ones. In this case, we can learn from paragraph to paragraph to find how the uncle treats Hazel and her younger brother, for instance. In the story, the narrator's reaction upon the behavior of the adult people around her is also described. The long paragraph is used by the writer to illustrate certain situations faced by the narrator, especially on unexpected ones. It seems that through the lines, the narrator rejects or protests on some of her family values. The writer gives an emphasis telling the readers that at a certain time, adults are permitted to tell lies to children. Another thing is information about a misunderstanding where children tend to take adult's speech for granted, for real. The explanation is children are still difficult to differentiate a joke and a reality. As the writer of Gorilla, My Love, Bambara uses many symbolic dictions to describe her ideas about Afro-American people. This study analyzes the following quoted lines: "And my Daddy yellin to granddaddy to get him a ladder cause Big Brood actin the fool, his mother side of the family showin up." This study finds that the word of ladder here is interesting. A ladder is a tool to climb up of something. This study believes that the Big Brother wants to get a higher position in playing his role in life. A ladder is like small stairs, the journey in life is symbolically written as a ladder where the Big Brother puts it carefully and he starts climbing it as an effort to reach something. But mama says that he actin the fool. Why? This study has an assumption that a fool thing is seen from mama's perspective. In other words, this study will say that different generation views this life with different "eyes". This study writes another quoted lines as a proof of this: "And my mama and her sister Daisy jumpin on them Romans beatin them with the pocketbook." The analysis goes: them refer to Big Brood and his generation. Jumpin on is a figurative diction as a reaction when Daddy yellin. Yellin versus jumpin in, a dramatic comparison. Then, the use of Romans; Romans refers to an ancient tribe with a high culture and civilized community with outstanding artefact, historically speaking. Why Bambara chooses Romans to describe the reaction of mama and aunt Daisy? This study believes that the contextual meaning of Romans here refers to the very famous rules which are acknowledged by people around the world. This study has an argument that since Romans are ancient but civilized tribe, it is used as a symbol to show readers how mama and her sister (Aunt Daisy) maintain their rules in handling family's problem. The time refers to the past, the value of the past is used for the present time. In addition, the narrator of the story has her own concept to shape the value of life which can be seen from the last sentence of the fifth paragraph: "And me in the parlor trying to do my arithmetic yellin shut it off."

The next is about the word of pocketbooks. A pocketbook refers to a small, handy book which is important for the one who brings it because it is always there in the pocket. This study assumes that it 


\section{Kustinah, Haryanti, Sri, Yuwono, Suhud Eko, \& Sholihah, Umi Afro-American Literature: The Analysis of Gorilla, My Love by Toni Cade Bambara}

has a symbolical meaning that it is a book of rules. Since Bambara writes them pocketbooks, this study believes that both mama and aunt Daisy adopt the same pocketbook; they keep the same rules. Because the Big Brood conducts a different pocketbook, he is written to be actin the fool. To strengthen the analysis, this study tells that Bambara's young narrator deploys a community-specific, self-confident, passionate, high-energy, vernacular language of resistance, and they celebrate the families and heritage that stand unshakably behind them. The narrator in Gorilla, My Love has several names given by her family: they call her Scout, Badbird, Miss Muffin, Hazel, Peaches and Precious. Uncle Jefferson calls her Scout; mama calls her Badbird while aunt Daisy calls her Miss Muffin. Sometimes mama calls her real name of Hazel, and Granddaddy uses Peaches and Precious. It is interesting to know that the narrator is given different names by her family.

Talking about family, so far from the five paragraphs that have been discussed here we see that three generations live in a house. The writer describes each of generation with its own value or rules of life. The following quoted lines underline the previous statement: "And Granddaddy Vale sayin Leave the boy alone, if that's what he wants to do with his life we ain't got nothin to say about it." Then Aunt Daisy givin him a taste of that pocketbook, fussin bout what a damn fool old man Franddaddy is. This study finds another interesting point. In the previous sentences we see that Daddy yellin because big Brood actin the fool and now Aunt Daisy fussin about that Granddaddy is a damn fool old man. There is also an interesting symbolic diction of taste. Why is Aunt Daisy said to givin Granddaddy a taste of the pocketbook? Literally speaking, taste means a small portion of something or in another context, we try a little bit of something in purpose of valuing something. This study analyzes that taste here is chosen as a symbol telling the readers that in this situation, Aunt Daisy tries her effort to persuade Granddaddy even though she has already known that Granddaddy has his own pocketbook. So, we may say that Aunt Daisy's effort is weak, she is unable to act against Granddaddy. That's why Bambara uses taste to describe Aunt Daisy's weak effort because taste inserts an instant reaction of powerless attempt in a symbolic meaning. Another thing that this study finds from the fifth paragraph is a sense of bitterness. This study senses a bitterness of life from the quoted lines like big Brood actin the fool, what a damn fool old man Granddaddy is. The diction of fool here is written twice for two characters. This study finds its strengthening point in the following quotation: "Then everybody jumpin in his chest like the time Uncle Clayton went in the army and come back with only one leg and Granddaddy say somethin stupid about that's life." Pay attention to the word stupid. This study believes that stupid is a synonym of fool. So, it can be said that an Afro-American family presented in Gorilla, My Love experiences a bitter life because readers get information that big Brood actin the fool, Granddaddy is a fool old man and Uncle Clayton is stupid. Bambara ends the fifth paragraph by writing her main character's reaction upon the circumstances around her. From the last sentence, we see that even in a young age, the narrator shows a strong reaction of protest by yellin them to shut up. See the quoted line where the writer uses the capital letter of $\mathrm{S}$ to give an emphasis on the strong voice of yellin done by the main character: "And me in the parlor trying to do my arithmetic yellin Shut it off." This study believes that the capital letter of $\mathrm{S}$ here is very important, it underlines the information about the character of Hazel as the narrator of the short story. Why is the word Shut begun with a capital letter? Since this is a literary work, we see here that the function of a capital letter is seen different from the same use of a capital letter in an ordinary text. Literary texts always play with symbols, even from a single letter. The use of a capital letter in an unusual position in a sentence can be interpreted as a clue of something. This study has decided to underline some key-words which are found in the fifth paragraph. Those key-words have been analyzed and we can see the relatedness among those words. The words are stupid, big fool, a damn fool. Big fool is used by mama for labelling Big Brood who actin the fool. This study sees a dramatic effect here where the word big refers to positive assumption and fool refers to negative assumption. So, this study believes that these two contrary words are used in purpose. Usually a dramatic effect is written to provoke a reader's mind in understanding the plot of the story. This story uses 
two settings of place to let the plot flow. The first setting is inside a car, another one is inside a theatre.

The sixth paragraph of the short story tries to illustrate Hazel's boredom on the film and also her anger because she and her brothers believe that the adults betray or tell lies too many times to children. From a reader's point of view, the sixth paragraph gives an extreme picture of a young Afro-American female character. From merely "a wrong film", that main character is written to be able to do a harmful thing, too brave in relating to her age. The writer gives many examples of daily situations faced by Hazel: in a theatre, in school, in the street, etc. In all unexpected or unwanted situation, Hazel is described in a similar behavior. She responds bravely and strongly to maintain her beliefs. The figure of mama is frequently used by Bambara as an influencing factor in shaping the main character's shaping of life. Using indirect speech, a reader may read the sentence uttered by Hazel in mentioning her mama and the life-values she got from mama. Hazel uses the word mama as a reasoning of her act. Mama teaches and gives advice to Hazel about many things in life. As a young girl, Hazel tries to comprehend the values that mama has tried to teach. This study believes that through her short story, Bambara also gives a highlight to women's voice and their significant role in the society. Hazel has the biggest portion in the story and the figure of mama is used for adding a strong intention about the ideas presented. In the sixth paragraph Hazel tells her story about what happened in the theatre and her experience with one of her teachers at school. Hazel as the narrator of the short story becomes very angry because the manager of the theatre announces that Gorilla, My Love is playin but he lies. From narrator's point of view, it is said that the adult people always underestimate kids. Hazel sees an adult person as a bad guy or a crook whenever he tells lies. Hazel feels very disappointed when she cannot have her money back which she thinks that it is her right because the manager plays a different film. This study gets another information that even at school, Hazel shows an open reaction anytime she experienced unsatisfying treatment from her teacher. The figure of Mama is written to defend Hazel's feeling. This study believes that the last sentence of the sixth paragraph inserts information that Mama is very brave, she gets Hazel's problem to School Board and when she talks, everybody there is like being hypnotized. A sense of admiration from a young girl to her Mama is shown here. It is said by [19] that mothers have been the glue that holds a family together because it is up to them to provide the loving care and support needed by growing children. If we see carefully, every paragraph of the short story presents a strong influence of the members of the family to the narrator's character. The given situations vary, where Granddaddy is presented, and also daddy or in another circumstances, Mama and Aunt Daisy or Aunt Jo are presented. The appearance of Big Brood and Baby Jason is illustrated as a kind of comparison, telling that Hazel is more active than them, the point is that Bambara shows that her narrator is very brave. This study finds that Bambara uses $I$ as the first person to narrate the story and it leads readers to learn Hazel's thoughts and opinion about life from the eyes of a young Afro-American girl. The main character uses I in narrating her stories but in turns, readers will sense a familial value, sometimes a racial pride or a claim of self-identity when Hazel shares her experience with members of the family. This study believes that as its writer, Bambara has divided the portion of each character to bring certain way of life owned by Afro-Americans. Several different situations with various setting of places are used to put the character's ideas. Toni cade Bambara uses both direct and indirect speech to describe the dialogues between her main character and supporting characters. Hazel as the central point, gives a clue to readers by using indirect speech to defend her own principles against unwanted behavior or attitude performed by the adults around her. The incident inside the theatre that makes Hazel very angry is narrated in two long paragraphs. Readers are led to a chronological act (thought) experienced by the main character of the short story.

From the seventh paragraph, this study finds a new member of narrator's family. Aunt jo, who is said to be the hardest head in the family. She is also said to be worse than Aunt Daisy. The explanation of course, is based on narrator's point of view. Through all paragraphs of the short story, readers will always be led to Hazel's point of view as the central point of Gorilla. My Love. The paragraph explains in details 
how Hazel feels very disappointed because the film entitled Gorilla, My Love is not played as it has been informed before. This study believes that through this paragraph, Bambara lays the idea of "our word should be our bond". She strengthens this idea by telling readers how hazel makes a fire inside the theatre and her daddy puts no blame on her. Bambara gives a message to readers that adults should keep their words even to children. When they say something, it means that they must do that, or in other words, children will be very mad if adults cannot keep their promises. Inside the story, Hazel defends herself by narrating her experiences when the adults around her always give unaccepted reasons when they do not keep their words. It is interesting to see that Hazel as a young girl, captures all words spoken an adult to be a serious thing, besides; the adults around her mean the opposite thing about their words. Readers are indirectly led to a horizon that young generations (in this case is represented by Hazel) see this life with a different point of view from what the adults believe. From the plot of the story, all readers will follow a related event that show narrator's disappointment upon adult's behavior. Starting from the opening paragraph until the last sentence of the short story, the ide remains the same. The idea tells us that young generation is able to show a sharp critic on adult's way of life and that young generation wants to be understood by the adult. They admit their point of view openly and protest whenever they are not heard. The paragraph also informs the readers that inside Hazel's family, there are a kind of negotiation between kids and parents: time when mama is described to be able to accept Hazel's explanation why she conducts such a thing. How the adults around Hazel respond to her behavior as a young generation, inserts an idea of self-identity. Inside the story, mama and Aunt Jo gives different names for Hazel. This study believes that the use of "Badbird" and "Miss Muffin" owns a symbolic meaning. Remember that the short story is talking about an Afro-American family. We surely will find its family values inside. Another information about lifeexperiences is added. The voice of Hazel represents her society's voice. Since a literary work is as a portrait of a society, we can say that Hazel as the narrator of the short story represents her generation among
Afro-Americans. This study can see a strong bond between Hazel and the members of her family and the story illustrates that they support each other despite of the difference of point of view among generations. The figures of Granddaddy, Daddy, Mama, Uncle Jefferson, Aunt Daisy and Jo, Big Brood and Baby Jason; all represent different generation. Logically speaking, it is a very common sense that in a society, each generation plays its role by using its own belief in shaping the recent life. The circumstances they face will always be responded differently but still, they always try to get close to a family ties. They have a strong bond as an Afro-American family. Three generations are set in the short story entitled Gorilla, My Love. Granddaddy stands as the first generation, Daddy, Mama, Hunca Bubba, Aunt Daisy and Aunt Jo are the second, Big Brood, Hazel and Baby Jason are the third generation. A symbolic interpretation arises when we study the first line in the opening paragraph where the narrator informs that her uncle, Hunca Bubba plans to get married. The interesting thing is, when the time comes, the uncle will change the name by starting using his real complete name Jefferson Winston Vale. This study believes that names are very important for Afro-Americans because it is a form of self-identity and it can also raise a self-pride in a larger context, a racial-pride. The clue for this idea is when we find that the narrator is given several names by her family. Those names mean a lot to the narrator. Her real name is Hazel, but when Mama calls her Badbird, it leads to certain situation. When Granddaddy calls her Scout, it leads to a different situation. Again, this phenomenon appears when Aunt Jo calls her Miss Muffin and Granddaddy calls her Peaches. If we think deeply about this, we may assume that those names are used to underline something. Something which belongs to certain values represented by the narrator of the short story. Back to the basic theory of what a literary work is, it is clear that Bambara creates a short story here to represent her society. From a small picture of how a young girl gets an unwanted situation, Bambara wants her readers to understand the ideas behind an event. Not merely just an unwanted film, Gorilla, My Love has been used as other small portrait of society where the narrator shows openly her feeling about the incident related to the film. It is said in the story that the film 
about gorilla has been replaced by a film on Jesus. Hazel who is played as the narrator sees it as a boredom since it has been repeatedly performed in the theatre.

\section{CONCLUSION}

\section{a. The Literariness of the text}

This study finds the first clue of symbolic dictions from several alias given for the narrator of the short story. The analysis of this study has made an explanation how the writer of the short story uses those alias to perform various situations faced by Hazel. Another symbol used by the writer of the short story is the appearance of Uncle. The narrator's uncle plays an important role in the story because this study believes that the word uncle here is contrasted to the word of "Uncle Sam". The first refers to the figure who has the first portion inside the story. The second refers to a wider context of uncle; it leads to a meaning that Uncle Sam is an alias of The United States of America. This study has discussed about this and supported by the mental evidences taken from the text. Readers can prove the theory of Minor to Manor. A literary work speaks for the universe. Gorilla, My Love never talks about gorilla, a bigprotected animal, but the work illustrates about beliefs, family values, self-pride and universal conflict. Its significance can still be seen at present time. The Afro-Americans as the characters of the short story are the representation of human in this world. People everywhere have a strong ties with their family. And people usually have their ow pride on their race.

\section{b. The way the literariness pictures the real life (the universe)}

Toni Cade Bambara sets the plot into eleven long paragraphs. She builds a frame to hold the elements of a short story in her wanted package. Starting from a car journey that stands as a symbol of life journey in the opening paragraph, she introduces the main character. This study finds a vivid characteristic of a short story: an event of life experienced by its main character becomes the focus of the plot. The various situations narrated in the story underline the points of understanding. In the analysis, this study shows that many times Hazel speaks beyond her age. This study believes that Bambara is trying to say that in real life, kids can act beyond adult's expectation.

\section{c. The Proof of Mental Evidences taken from the text}

The follwing are quotations from the short story which stand as mental evidences for the analysis. The underlined words are used as a key-word to make an interpretation.

“. ...... And Granddaddy Vale sayin Leave the boy alone, if that's what he wants to do with his life we ain't got nothin to say about it."

". . . . . .I knock on the door and $\mathrm{I}$ am furious. And I am alone ......."

“.......And now I'm really furious cause I get so tired grownups messin over kids just cause they little and can't take em to court."

“. . . . . . . Cause that's the way I was raised. Like my Mama say in one of them situations when I won't back down, Okay Badbird, you right. Your point is welltaken."

“.......Aunt Daisy, she say, You absolutely right Miss Muffin, which also ain't my real name but the name she gave me one time when I ......"

“....... Then Granddaddy Vale speak up. "Look here, Precious, it was Hunca Bubba what told you them things. This here, Jefferson Winston Vale." And Hunca Bubba say, "That's right. That was somebody else. I'm new somebody."

\section{ACKNOWLEDGEMENT}

University of Widya Dharma Klaten for the 2020 Internal Research Grant

\section{REFERENCES}

[1] He, Y. (2020). Rethinking 'minor literature' and 'small literature' as 'secondary zone literature. 2021. Territories: A Trans-Cultural Journal of Regional Studies, Vol 2(1), p. 32-48. https://doi.org/10.5070/T22144835

[2] University Writing Center. (2021). analyring novel and short stories. Rudder: Texas A\&M university Press.

https://writingcenter.tamu.edu/Students/Writin g-Speaking-Guides/Alphabetical-List-ofGuides/Academic-Writing/Analysis/AnalyzingNovels-Short-Stories 
Kustinah, Haryanti, Sri, Yuwono, Suhud Eko, \& Sholihah, Umi Afro-American Literature: The Analysis of Gorilla, My Love by Toni Cade Bambara

[3] Comfort, M. (1998). Liberating figures in Toni Cade Bambara's 'gorilla, my love'. Studies in American Humor Vol 3(5), p. 76-96. https://www.jstor.org/stable/42573360?seq=1 \#metadata info tab contents

[4] Cornett, D. (2017). Big picture, small picture: Context for Toni Cade Bambara's gorilla, my love. Project MUSE Mission.

https://www.bhamcityschools.org/cms/lib5/A L01001646/Centricity/Domain/4460/gorillamy-love.pdf

[5] Mursalim, M. (2019). A sociological approach of literature in short story senyum yang kekal by Korrie Layun Rampan. In The 28th International Conference on Literature (ICoL) XXVIII.

http://jurnal.unsyiah.ac.id/ICOL/article/view/ $\underline{14439}$

[6] Aras, G. (2015). Personality and individual differences: literature in psychology - psychology in literature. In 3rd World Conference on Psychology and Sociology, Procedia - Social and Behavioral Sciences $185,250-257$.

https://core.ac.uk/download/pdf/82271267.pd $\underline{\mathrm{f}}$

[7] Setiaji, A. B. (2019). Kajian psikologi sastra dalam cerpen 'perempuan balian' Karya Sandi Firli (Study of Psychology of Literature in "The Women of Balian" Short Works of Sandi Firly).," Lingue Bahasa, Budaya, dan Sastra, vol. 1, no. 1, pp. 21-35. https://jurnal.iainambon.ac.id/index.php/lingue $\angle$ article/view/1176

[8] Rahayu, N. P., Lestari, R. S., Anjani, C. \& Firmansyah, D. (2018). Aspek kepribadian tokoh utama dalam cerpen cerita pendek yang panjang karya Hasta Indriyana: Kajian psikologi sastra, dan implementasinya sebagai bahan ajar sastra di SMA," Parole, vol. 1(2), p. 115-126. https://journal.ikipsiliwangi.ac.id/index.php/par ole/article/view/177

[9] Ahmadi, A. (2020). Promoting personality psychology through literary learning: An appreciative-reflective study. International Journal of Innovation, Creativity, and Change, Vol. 11(7) p. 529-540. https://ijicc.net/images/vol11iss7/11744 Ahm adi 2020 E R.pdf

[10]Dwyer, R., Davis, I., \& Emerald, E. (2017). Narrative Research in Practice, Stories from the Field. Singapore: Springer Nature.

https://www.springer.com/gp/book/97898110 15779

[11]Cherry, K. (2019, March 15). Self-Determination Theory and Motivation. Verywellmind. Retrieved from https://www.verywellmind.com/what-isself-determination-theory-2795387

[12]Halliday, A. S. (2020). Black girls' feistiness as everyday resistance in Toni Cade Bambara's gorilla, my love. Palimpsest: A journal of Women, Gender, and the Black International, Vol. 9(1), p. 50 64. https://muse.jhu.edu/article/754668/pdf

[13]Puglisi, B. (2013, July 17). The psychology of disappointment \& our characters. Writers Helping Writers. Retrieved from

https://writershelpingwriters.net/2013/07/thepsychology-of-disappointment-our-characters

[14]Syofyan, D. (2018, January 8). Essay: sociology of literature. The Jakarta Post. Retrieved from https://www.thejakartapost.com/news/2018/0 1/08/essay-sociology-literature.html

[15]Creswell, J. W. (2015) Penelitian kualitatif \& desain riset: Memilib di antara lima pendekatan (A. L. Laquardi, Trans.) Yogyakarta: Pustaka Pelajar.

[16]Bambara, T. C. (1972). Gorilla, my love. New York: Random House, Inc,.

[17]Endraswara, S. Metodologi penelitian sastra: Epistemology, model, teori dan aplikasi. Jakarta: PT. BUKU SERU.

[18]Giddens, A. (1991). Modernity and self-identity, self and society in the late modern age. California: Stanford University Press. 